\title{
MBOAT2 Gene
}

National Cancer Institute

\section{Source}

National Cancer Institute. MBOAT2 Gene. NCI Thesaurus. Code C114571.

This gene is involved in lysophospholipid metabolism. 